JURNAL SEKRETARIS \& ADMINISTRASI BISNIS

Jurnal homepage: http://jurnal.asmtb.ac.id/index.php/jsab

\title{
ANALISIS PERSAINGAN TARIF ANTARA TELKOMSEL DAN INDOSAT DI INDUSTRI TELEKOMUNIKASI
}

Devi Melisa Damiri

Pascasarjana Administrasi Bisnis, Fakultas Ilmu Sosial dan Ilmu Politik, Universitas Padjadjaran devi15009@mail.unpad.ac.id

\section{ARTICLE REPORT}

Article annals:

Received $20^{\text {th }}$ July 2017

Received in revised form $2^{\text {nd }}$ October 2017

Accepted $24^{\text {th }}$ October 2017

Keywords:

Unfair Competition

Monopolistic

Telecommunications Industry

\begin{abstract}
Established Law No. 5 of 1999 on the prohibition of monopolistic practices and unfair business competition cannot be separated from IMF pressure on the Indonesian government on the government to combat monopolistic practices and unfair business competition that occurred in Indonesia by immediately enacting the legislation. The purpose of this study is analyzing the telecommunications industry price war that occurs between the Telkomsel operator and Indosat Ooredoo against unfair competition. The method used in this research is descriptive method of analysis. Data used are secondary data. Results of analysis showed that Indosat Ooredoo trying to overthrow the corporate image Telkomsel in their campaign fare $R p$ 1,- and Telkomsel operator also negotiate interconnection prices unfair to Indosat Ooredoo.
\end{abstract}

@ 2017 ASMTB PRESS

\section{Pendahuluan}

Peran teknologi komunikasi dan informasi semakin signifikan dalam perkembangan ekonomi dan bisnis saat ini, dibalik perkembangan tersebut terdapat peran dari para pelaku usaha di industri telekomunikasi. Dinamika persaingan usaha sektor telekomunikasi semakin ketat, sehingga operator seluler berlomba-lomba menciptakan startegi bisnis agar dapat meraih loyalitas pelanggan dalam situasi yang cenderung mengalami kejenuhan pasar. Adanya peningkatan jumlah pelanggan tidak diikuti dengan bertambahnya nilai pendapatan di industri operator seluler. Di sadari oleh pemerintah bahwa persaingan antar operator tersebut dapat memicu timbulnya persaingan yang tidak sehat, oleh karena itu sebagai wujud kesungguhan dari pemerintah dalam menciptakan iklim usaha sehat telah diupayakan diantaranya dengan membuat suatu produk perundang-undangan tentang larangan praktek monopoli dan persaingan usaha tidak sehat. Larangan ptaktek monopoli di tegaskan di dalam UU No. 5 Tahun 1999 yang mulai di berlakukan di Indonesia sejak tanggal 5 September 2000. UU ini merupakan hasil dari proses reformasi ekonomi danpolitik yang diharapkan mampu menciptakan persaingan usaha yang sehat (Gelhorn dan Wijaya, 2002). Menurut Muladi bahwa dalam UU Anti monopoli dapat dikatakan secara komprehensif, karena sebenarnya secara pragmentaris, batasanbatasan yuridis terhadap praktik-praktik bisnis yang tidak sehat atau curang dapat ditemukan secara tersebar di berbagai hukum positif, tetapi karena sifatnya yang sektoral, perundang-undangan tersebut sangat tidak efektif untuk (secara konseptual) memenuhi berbagai indikator sasaran yang ingin dicapai oleh undang-undang persaingan sehat tersebut. 
Persaingan usaha terus terjadi hingga saat ini, tidaklah menjadi masalah apabila persaingan tersebut sehat dan konsumen tidak menjadi pihak yang dirugikan atas persaingan tersebut. Operator telekomunikasi saling melakukan kampanye perang tarif dengan promosi yang menyudutkan operator tetangga. Perang tersebut terjadi dan ramai dibahas di media sosial, operator Indosat Ooredoo melancarkan promosi yang memojokkan Telkomsel. Oleh karena itu tujuan penelitian ini adalah untuk membahas dan menganalisis lebih lanjut mengenai perang tarif industri telekomunikasi yang terjadi antara operator Telkomsel dengan Indosat Ooredoo terhadap persaingan usaha tidak sehat.

Penelitian yang dilakukan oleh Achjar dan Ibrahim (2008) bahwa Tarif jasa telekomunikasi menjadi salah satu isu penting setelah liberalisasi industri telekomunikasi di berbagai Negara termasuk Indonesia. Melalui deregulasi dengan dihapuskannya monopoli, tarif jasa telekomunikasi diharapkan semakin kompetitif sehingga konsumen memperoleh manfaat dari turunnya tarif. Terdapat indikasi bahwa tarif seluler di Indonesia relative masih tinggi dibandingkan dengan tarif di beberapa negara sehingga secara relatif kesejahteraan yang diperoleh konsumen pelanggan jasa telekomunikasi seluler nasional lebih rendah dibandingkan dengan tarif negara lain yang menjadi referensi. Penurunan tarif sebenarnya justru akan meningkatkan total pendapatan karena adanya respons dari konsumen untuk menambah permintaan. Kerugian karena penurunan tarif lebih kecil dibandingkan dengan tambahan keuntungan.

Dalam penerapan persaingan sektor telekomunikasi terdapat pihak-pihak yang sering memberikan perlindungan ataupun privileges kepada para pelaku bisnis tertentu, hal ini dapat menimbulkan persaingan yang tidak sehat serta memicu timbulnya praktek monopoli. Kasus persaingan tidak sehat serta dugaan monopoli pada sektor telekomunikasi telah terbukti dengan adanya pelanggaran yang di lakukan oleh Grup Temasek. Pernyataan bersalah ini dibacakan dalam sidang pembacaan perkara No 7/KPPU-L/2007 tentang dugaan pelanggaran pasal 27 huruf 1 UU No 5/1999 mengenai Larangan Praktek Monopoli dan Persaingan Usaha Tidak Sehat di kantor KPPU. Dalam pembacaan perkara tersebut terdapat 10 pihak terlapor, yang semuanya merupakan kepanjangan tangan dari Temasek. Terlapor I : Temasek Holdings Pte.Ltd, Terlapor II : SingTel, Terlapor III : STT Communications Ltd, Terlapor IV : Asia Mobile Holdings Company Pte Ltd, Terlapor V: Asia Mobile Holdings Pte Ltd,Terlapor VI: Indonesia Communications Ltd, Terlapor VII: Indonesia Communications Pte Ltd, Terlapor VIII : Singapore Telecommunications Pte Ltd, Terlapor IX : Singapore Telecom Pte Ltd. Dalam sidang ini, KPPU menyatakan adanya hubungan sebab-akibat yang jelas antara kepemilikan silang (cross ownership) Temasek dengan kerugian di industri seluler. KPPU membeberkan bahwa kepemilikan silang (cross ownership) Temasek di Indosatdan Telkomsel telah menimbulkan kerugian konsumen di industri seluler sebesar Rp 14,7 triliun-30,8 triliun selama 2003-2006 (Hasan, 2008).

Berbagai negara telah memiliki undang-undang dan aturan yang mengatur tercipta dan terpeliharanyapersaingan usaha yang sehat. Definisi pesaing adalah perusahaan yang menghasilkan atau menjual barang atau jasa yang sama atau mirip dengan produk yang kita tawarkan (Kasmir, 2007). Persaingan usaha sehat adalah persaingan yang pelaku usahanya tidak terpusat pada tangan tertentu dan tersentralisasi pada beberapa pihak saja, akan tetapi berjalan sesuai mekenisme pasar yang sehat yaitu dalam dunia ekonomi semua pelaku usaha mempunyai hak dan kewajiban yang sama (Siswanto, 2002). Persaingan usaha sehat adalah dimana bila ada perikatan berbentuk perjanjian tidak merugikan secara sepihak kepada pihak lain yang tidak terlibat dalam perjanjian tersebut.

Alfred Marshal (dalam Sirait 2004) seorang ekonomi terkemuka sampai mengusulkan agar istilah persaingan digantikan dengan istilah "economic freedom" (kebebasan ekonomi) dalam menggambarkan atau mendukung tujuan positif dari proses persaingan. Oleh sebab itu pengertian kompetisi atau persaingan usaha dalam pengertian yang positif dan independent sebagai jawaban terhadap upaya dalam segi keuntungan untuk menarik pembeli agar mencapai untung. Beberapa aspek positif persaingan usaha dalam perspektif ekonomi, yaitu sebagai berikut:

1. Persaingan merupakan sarana untuk melindungi para pelaku ekonomi terhadap eksploitasi dan penyalahgunaan. Kondisi persaingan menyebabkan kekuatan ekonomi para pelaku ekonomi tidak terpusat pada tangan tertentu. 
2. Persaingan mendorong alokasi dan realokasi sumber-sumber daya ekonomi sesuai dengan keinginan konsumen, karena ditentukan oleh permintaan, perilaku para penjual dalam kondisi persaingan akan cenderung mengikuti pergerakan permintaan para pembeli.

3. Persaingan bisa menjadi kekuatan untuk mendorong penggunaan sumber daya ekonomi dan metode pemanfaatannya secara efisien. Dalam hal perusahaan bersaingan secara bebas, maka mereka akan cenderung menggunakan sumber daya yang ada secara efisien.

4. Persaingan bisa merangsang peningkatan mutu produk, pelayanan, proses produksi, dan teknologi. Dalam kondisi persaingan setiap pesaing akan berusaha mengurangi biaya produksi serta memperbesar pangsa pasar.

Sementara di Indonesia, telah terdapat Undang-Undang (UU) No. 5 tahun 1999 yang mengatur tentang Larangan Praktek Monopoli dan Persaingan Usaha Tidak Sehat. Lahirnya Undang-undang agar pemerintah segera memberantas praktek-praktek monopoli dan persaingan usaha tidak sehat yang terjadi di Indonesia dengan cara segera memberlakukan undang-undang tersebut diatas. Dalam hal ini, Komisi Pengawas dan Persaingan Usaha (KPPU) yang diresmikan pada tanggal 7 Juni 2000 dibentuk sebagai implementasi dari Undang-Undang No. 5 tahun 1999 mengenai Larangan Praktek Monopoli dan Persaingan Usaha Tidak Sehat. Lembaga ini berfungsi memeriksa berbagai pihak yang diduga melanggar UU No. 5 tahun 1999, memberi putusan dan menjatuhkan sangsi kepada para pelaku usaha yang terbukti melanggar usaha tersebut (Hasan, 2008).

Tujuan Undang-Undang (UU) persaingan usaha adalah Undang-undang No. 5 Tahun 1999 tentang Larangan Praktek Monopoli dan Persaingan Usaha Tidak Sehat (UU No.5/1999) yang bertujuan untuk memelihara pasar kompetitif dari pengaruh kesepakatan dan konspirasi yang cenderung mengurangi dan atau menghilangkan persaingan. Kepedulian utama dari UU persaingan usaha adalah promoting competition dan memperkuat kedaulatan konsumen. Inti dari UU No. 5 Tahun 1999 adalah melarang kesepakatan, aktivitas dan penyalahgunaan dominasi pasar yang dilakukan satu atau beberapa perusahaan. Kesepakatan yang dilarang antara lain termasuk oligopoli, penentuan atau diskriminasi harga, predatory pricing, pembagian pasar, group boycotts, kartel, perserikatan antar perusahaan, oligopsoni, vertical integration, exclusive dealing dan perjanjian dengan pihak asing yang dapat mengakibatkan praktek usaha tidak sehat. Aktivitas yang dilarang antara lain: monopoli, monopsoni, market control, predatory pricing, persekongkolan dalam penawaran dan mendapatkan rahasia pesaing (Hasan, 2008).

\section{Metode Penelitian}

Objek penelitian merupakan suatu atribut atau sifat atau nilai dari orang, objek atau kegiatan yang mempunyai variasi tertentu yang ditetapkan oleh peneliti untuk di pelajari dan kemudian ditarik kesimpulannya (Sugiyono, 2010). Objek penelitian ini dilakukan pada Operator Seluler Telkomsel dan Indosat Ooredoo sebagai perusahaan yang bergerak di bidang layanan telekomunikasi. Penelitian ini menggunakan jenis penelitian studi literatur dengan mencari referensi teori yang relevan dengan kasus atau permasalahan yang ditemukan. Studi literatur adalah cara yang dipakai untuk menghimpun data-data atau sumber-sumber yang berhubungan dengan topik yang diangkat dalam suatu penelitian. Referensi teori yang diperoleh dengan jalan penelitian studi literatur dijadikan sebagai acuan dasar dan alat utama bagi praktek penelitian ditengah lapangan.

Data yang digunakan dalam penelitian ini adalah data sekunder. Sumber data sekunder merupakan data primer yang telah diolah lebih lanjut dan disajikan baik oleh pihak pengumpul data primer atau pihak lain misalnya dalam bentuk tabel-tabel atau diagram-diagram (Umar, 2000). Sumber data sekunder adalah sumber yang tidak langsung memberikan data kepada pengumpul data misalnya melalui orang lain atau melalui dokumen-dokumen. Data sekunder diperoleh dari data-data yang berasal penelitian terdahulu, studi kepustakaan seperti buku-buku, jurnal, artikel, berita dan makalah yang berkaitan dengan objek penelitian.

Metode penelitian yang digunakan adalah menggunakan metode deskriptif analisis. Metode penelitian deskriptif adalah penelitian yang dilakukan untuk mengetahui keberadaan variabel mandiri, baik hanya pada satu variabel atau lebih (variabel yang berdiri sendiri) tanpa membuat 
perbandingan dan mencari hubungan variabel itu dengan variabel yang lain. Metode penelitian deskriptif analisis untuk menganalisa data dengan cara mendeskripsikan atau menggambarkan data yang telah terkumpul sebagaimana adanya (Sugiyono, 2010).

\section{Hasil Penelitian dan Pembahasan}

Industri telekomunikasi seluler di Indonesia menyimpan potensi ekonomi pasar yang sangat menjanjikan bagi pelaku usaha sektor telekomunikasi. Persaingan sering dikonotasikan negatif karena dianggap mementingkan kepentingan sendiri, meskipun pada kenyataannya seorang manusiasebagai individual maupun anggota suatu organisasi secara ekonomi tetap akan berusaha mendapatkan keuntungan yang sebesar-besarnya. Kompetisi di sektor telekomunikasi terus terjadi, seharusnya hal ini dapat meningkatkan gairah persaingan sehat di antara pengusaha telekomunikasi di Indonesia. Kerap terdengar persaingan yang ketat antara operator milik perusahaan Telkom (BUMN) yaitu Telkomsel dengan operator Indosat Ooredoo yang kini sahamnya dimiliki Qatar Telecom (Qtel) Q.S.C. (Qtel) atas nama Ooredoo Asia Pte. Ltd. Perang antara dua operator telekomunikasi Indosat Ooredoo dan Telkomsel terkait perang tarif belakangan menjadi sorotan beberapa pihak.

Bermunculan spanduk yang menyindir tarif Telkomsel lebih mahal dibanding Indosat Ooredoo. Dalam Kompasiana (2016), bahwa saat ini persaingan industri telekomunikasi khususnya selular sudah semakin sengit. Indosat Ooredo menyatakan bahwa persaingan usaha telekomunikasi di luar Jawa terbilang tak sehat lagi. Dalam Viva (2017) Indosat Ooredoo dilaporkan memiliki jumlah menara telekomunikasi atau base transceiver station (BTS) tercatat 58.175 unit di kuartal I 2017, atau meningkat 5.849 unit dari 52.326 unit pada kuartal yang sama tahun lalu. Pulau Jawa memiliki BTS dengan jumlah terbanyak di antara pulau lainnya di Indonesia. Sedangkan dalam Kompas (2016) Hingga penghujung tahun 2016 ini, Telkomsel mengklaim jumlah BTS Telkomsel sudah mencapai 120.000 unit, dengan penambahan sekitar 20.000 BTS sepanjang 2016. Jumlah kepemilikan tersebut telah melebihi dari setengah jumlah kepemilikan operator Indosat Ooredoo, meskipun harus di sadari bahwa peran Telkomsel sebagai anak perusahaan PT. Telekomunikasi Indonesia yang memang sudah seharusnya memiliki peran lebih dalam kemajuan negara Indonesia, dibandingan Indosat Ooredoo yang sebagian besar sahamnya di miliki oleh perusahaan asing. Ketimpangan jaringan tersebut cukup sulit untuk dikejar oleh operator lain sehingga dapat memicu timbulnya polemik yang berkepanjangan apabila tidak ditemukan solusi yang menguntungkan bagi semua pihak perusahaan di sektor telekomunikasi.

Berdasarkan pernyataan Ketua Umum Apnatel dalam Kompas (2016) bahwa kunci kemenangan di telekomunikasi itu coverage, capacity, dan quality service. Keunggulan covarege yakni harus ada wilayah layanan baru bisa masuk pasar. Keunggulan Telkomsel atau Telkom dari pesaingnya sekarang karena konsisten dalam berinvestasi untuk memperluas jaringan. Pada contoh di kawasan timur Indonesia, pesaing Telkom Group pernah memiliki kesempatan untuk membangun backbone secara murah melalui konsorsium Palapa Ring beberapa tahun lalu, tetapi konsorsium itu bubar karena beranggapan investasi di daerah timur Indonesia tak layak secara ekonomi. Anggota konsorsium itu ada Telkom, Indosat, XL, dan lainnya. Beliau pun menambahkan bahwa Telkom membangun sendiri jaringan di Indonesia Timur dan terus berlanjut, dengan tujuan untuk menjadikan Indonesia sebagai global hub. Dengan demikian keunggulan yang dimiliki Telkomsel telah menjadi salah satu faktor yang membuat jaringan Telkomsel semakin terdepan. Berdasarkan pernyataan tersebut, Telkomsel nyatanya tidak melakukan pelanggaran maupun monopoli seperti yang dituduhkan sebelumnya.

Persaingan usaha sehat adalah persaingan yang pelaku usahanya tidak terpusat pada tangan tertentu dan tersentralisasi pada beberapa pihak saja, akan tetapi berjalan sesuai mekanisme pasar yang sehat yaitu dalam dunia ekonomi semua pelaku usaha mempunyai hak dan kewajiban yang sama. Dalam kasus perang tarif yang sedang terjadi dapat dikatakan Indosat mengindikasikan kearah persaingan usaha yang tidak sehat. Jika dilihat dari sisi Indosat bahwa promosi perang tarif Rp. $1 \mathrm{ke}$ semua operator di Pulau Jawa secara terang-terangan telah membawa nama operator Telkomsel pada 
kampanyenya, hal ini sebagai salah satu cara bahwa operator Indosat Ooredoo berusaha untuk menurunkan market share operator Telkomsel dengan menjatuhkan citra perusahaan. Promosi secara gencar dan terbuka boleh saja di lakukan sesuai dengan strategi bisnis yang inovatif, kreatif dan menarik demi meningkatkan keuntungan perusahaan. Sebagaimana diketahui, persaingan mampu menciptakan inovasi dan kreatifitas dan setiap kompetisi yang ada dalam sistem yang positif akan menciptakan manusia-manusia yang unggul dan kreatif. Perlu dipahami, alasan persaingan yang tidak terfokus pada hal-hal kemajuan kualitas perusahaan, akan menciptakan kerugian, terlebih jika persaingan tersebut menghasilkan dampak negatif kepada lingkungan sekitarnya. Kewajiban setiap perusahaan dalam menjaga citra perusahaan lain dengan cara tidak saling menjatuhkan operator tertentu.

Penentuan tarif Rp.1 ke semua operator pun tidak hanya berdampak bagi operator Telkomsel, akan tetapi tarif tersebut dapat mematikan perusahaan operator sejenis lainnya yang tidak mampu mengikuti dan mengimbangi pasar. Tarif Indosat tersebut sangat jauh berbeda dengan tarif yang dimiliki operator-operator lainnya, sehingga mampu menarik banyak minat konsumen untuk meninggalkan operator yang lebih mahal ketimbang Indosat Ooredoo. Hal ini akan berdampak negatif dan menghambat pelaku usaha lain yang berpotensi menjadi pesaing untuk memasuki pasar telekomunikasi. Perlu adanya campur tangan pihak pemerintah untuk mengkaji ulang atas penentuan tarif dasar operator telekomunikasi seluler di Indonesia. Persaingan usaha sehat adalah dimana bila ada perikatan berbentuk perjanjian tidak merugikan secara sepihak kepada pihak lain yang tidak terlibat dalam perjanjian tersebut, maka dapat dinyatakan bahwa penentuan tarif Rp.1 dapat menimbulkan kerugian pada pihak lain, operator seluler secara khususnya.

Persaingan yang dirawat dan dijaga akan menghasilkan manfaat yang positif, dan menghindarkan semua potensi negatif yang dapat merusak sumber daya manusia. Dapat disimpulkan bahwa operator-operator seluler di Indonesia sangat diuntungkan dengan struktur industri telepon seluler yang mengarah ke bentuk oligopoli. Persaingan bisa berlangsung secara langsung bisa juga berbentuk persaingan tetapi tidak secara langsung. Meskipun Indosat sendiri melakukan tindakan persaingan tidak sehat secara nyata ketika melakukan kampanye perang tarif Rp. 1,- dan menyebarkan iklannya melalui media online secara terbuka. Tujuan perusahaan dalam menjalankan usaha adalah untuk memenangkan persaingan. Oleh karena itu, setiap perusahaan memiliki strategi tersendiri untuk mematikan lawannya. Dalam CNN Indonesia (2016) Pihak Pemerintah melalui Badan Regulasi Telekomunikasi Indonesia (BRTI), mengungkapkan akan memanggil dua operator tersebut sebagai salah satu upaya untuk meredakan persaingan tersebut yang dapat meicu persaingan tidak sehat serta melakukan penyelidikan lebih lanjut atas dugaan monopoli yang diujukan kepada operator Telkomsel. Persaingan usaha tidak sehat adalah persaingan antar pelaku usaha dalam menjalankan kegiatan produksi dan atau pemasaran barang dan atau jasa yang dilakukan dengan cara tidak jujur atau melawan hukum atau menghambat persaingan usaha.

Tarif jasa telekomunikasi menjadi salah satu isu penting industri telekomunikasi di berbagai negara termasuk Indonesia. Melalui deregulasi dengan dihapuskannya monopoli, tarif jasa telekomunikasi diharapkan semakin kompetitif sehingga konsumen memperoleh manfaat dari turunnya tarif. Berdasarkan hasil pengumpulan data dan teori yang berkaitan di atas maka dapat dikatakan bahwa dalam kasus perang tarif antara operator seluler Telkomsel dan Indosat, yakni kedua operator tersebut sama-sama terbukti mengarahkan kepada persaingan usaha yang tidak sehat serta perlu dilakukan pengawasan oleh Badan Regulasi Telekomunikasi Indonesia (BRTI) dan KPPU. Praktek-praktek ini mungkin sekali tampak tidak adil, tetapi bukan berarti bahwa telah terjadi pelanggaran terhadap undang-undang persaingan. Selain itu, meskipun proses peningkatan kompetisi di Indonesia menemui banyak hambatan, baik dari segi undang-undang itu sendiri maupun dari segi implementasi, dalam beberapa tahun ini telah terjadi berbagai macam kemajuan. Kesadaran akan pentingnya kompetisi atau persaingan itu sendiri patut dihargai dan arah menuju usaha yang lebih sehat. 


\section{Simpulan}

Industri telekomunikasi di Indonesia merupakan industri yang mengalami perkembangan yang pesat. Konsekuensi logis dari adanya kompetisi adalah munculnya efisiensi sehingga struktur biaya menjadi lebih rendah yang selanjutnya menyebabkan tarif yang dibebankan kepada konsumen menjadi lebih rendah pula. Secara teoritis, dalam persaingan usaha yang sehat, selisih antara tarif dengan biaya tambahan (marginal cost) yaitu biaya yang dibutuhkan untuk setiap tambahan satu unit output tidak terlalu besar. Analisis yang terlalu fokus pada aspek tarif tanpa memperhatikan aspek biaya serta pola permintaan pasar akan menimbulkan bias untuk sampai pada kesimpulan bahwa telahterjadi kecenderungan praktek persaingan usaha tidak sehat.

Secara umum Indosat sendiri melakukan tindakan persaingan tidak sehat secara nyata ketika melakukan kampanye perang tarif Rp.1,- dan menyebarkan iklannya melalui media online secara terbuka. Promosi perang tarif Rp.1 ke semua operator di Pulau Jawa secara terang-terangan telah membawa nama operator Telkomsel pada kampanyenya, hal ini sebagai salah satu cara bahwa operator Indosat Ooredoo berusaha untuk menurunkan market share operator Telkomsel dengan menjatuhkan citra perusahaan.

Perkembangan total pelanggan telepon seluler GSM tumbuh dengan sangat cepat. Telkomsel yang berperan sebagai operator dominan di Indonesia, terbukti memiliki negosiasi harga Interkoneksi yang tidak adil antara operator yang di tawarkan oleh Telkomsel terhadap operator-operator seluler lainnya. Hal ini dirasakan oleh operator Indosat yang mendapatkan harga Interkoneksi lebih mahal dari yang ditawarkan kepada operator Tri. Operator dominan sebagai Pelaku usaha dilarang menggunakan posisi dominan baik secara langsung maupun tidak langsung untuk menetapkan syaratsyarat perdagangan dengan tujuan untuk mencegah dan atau menghalangi konsumen memperoleh barang dan atau jasa yang bersaing, baik dari segi harga maupun kualitas. Tidak dapat dipungkiri bahwa hal tersebut menimbulkan kesan bahwa pihak Telkomsel mengahalangi operator Indosat untuk semakin maju dan berkembang dalam mengambil market share usaha telekomunikasi seluler, serta secara sengaja menghambat perkembangan Indosat sehingga tidak efektif bersaing dengan Telkomsel.

Dampak dari adanya persaingan tarif antar-Telkomsel dan Indosat mampu memberikan kontribusi negatif bagi berbagai pihak, baik dari segi operator seluler lainnya maupun berdampak kepada kerugian dari sisi konsumen apabila perang kedua operator tersebut tidak segera di lakukan mediasi oleh BRTI agar kedua belah pihak dapat menemukan kesepakatan penyelesaiannya. Setiap kondisi penurunan tarif akan mengakibatkan surplus konsumen (consumer surplus), konsumen dihadapkan pada tingkat harga yang lebih murah sehingga daya belinya meningkat. Sebaliknya, setiap kenaikan tarif menyebabkan terciptanya kehilangan konsumen. Dengan penentuan tarif terlalu rendah maka dapat membuat operator sejenis kehilangan pelanggannya. Tingkat persaingan akan menyebabkan perusahaan operator seluler yang ada berusaha untuk mempertahankan atau merebut pangsa pasar yang ada bukan hanya dengan menurunkan tingkat harga, akan tetapi juga dengan mengembangkan fitur dan layanan tambahan dari jasa Telekomunikasi Seluler yang diberikan.

Menurut Modjo (2008) bahwa peningkatan pangsa pasar layanan telekomunikasi seluler tentu memerlukan pondasi dan cakupan regulasi industri yang bukan hanya memadai, akan tetapi juga bisa memayungi inovasi produk dan proses yang kerap terjadi pada industri ini. Dengan kata lain, regulasi yang efektif pada industri telekomunikasi seluler diperlukan selain untuk menjamin adanya penetapan harga yang efisien dan perlindungan konsumen di satu sisi. Di sisi lain, regulasi yang efektif juga diperlukan untuk menjamin kedinamisan dan persaingan yang sehat dalam pasar telekomunikasi seluler. Kesadaran akan pentingnya kompetisi atau persaingan itu sendiri patut dihargai dan arah menuju usaha yang lebih sehat juga mulai berjalan di Indonesia. Perbaikan di masa mendatang diharapkan berjalan dengan efektif, baik dari sisi regulasi, praktek maupun jalinan kerjasama yang 
sehat di antara pelaku operator telekomunikasi seluler, sehingga mampu memberikan pelayanan dan kualitas maksimal kepada masyarakat tanpa membebankan dan merugikan masyarakat.

\section{Ucapan Terima Kasih}

Penulis mengucapkan Puji Syukur kepada Allah SWT telah memberikan kemudahan dan kelancaran dalam penyelesaian penulisan ini. Terima kasih saya ucapkan kepada Bapak Anang Muftiadi atas segala ilmu pengetahuan dan bimbingan yang telah diberikan kepada penulis, sehingga jurnal ini dalam selesai dengan baik. Terima kasih pula kepada rekan-rekan Magister Administrasi Bisnis Unpad angkatan 2015 gelombang 2 atas kerjasama dan kekompakan yang terjalin.

\section{Daftar Pustaka}

Achjar, Nuzul. dan Ibrahim Kholilulrohman. (2008). Persaingan Industri Telekomunikasi dan Pengaruhnya Terhadap Kesejahteraan: Sebuah Tinjauan Pustaka. Jurnal Bisnis dan Ekonomi Politik, Vol.9 No.1: 29-40.

CNN Indonesia. (2016, Juni 23). Ajak Operator Lain 'Serang' Telkomsel, Bos Indosat Dikritik. Retrieved from http://www.cnnindonesia.com/teknologi/20160623161024-213-140455/ajakoperator-lain-serang-telkomsel-bos-indosat-dikritik/

CNN Indonesia. (2016, Juni 21). Selain Telkomsel, Indosat Juga Keluhkan Diskriminasi Telkom. Retrieved from https://www.cnnindonesia.com/teknologi/20160621171836-213139862/selain-telkomsel-indosat-juga-keluhkan-diskriminasi-telkom/

Gelhorn, dan Wijaya, Gunawan. (2002). Seri Hukum Bisnis: Merger dalam Perspektif Monopoli. Jakarta: PT. Raja Grafindo Persadah.

Hasan, M.Fadhil. (2008). Refleksi Persaingan Usaha pada Industry Telekomunikasi di Indonesia. Jurnal Bisnis dan Ekonomi Politik, Vol.9 No.1: 1-8.

Kasmir. (2007). Kewirausahaan. Jakarta: PT. Raja Grafindo Persada.

Kompas. (2016, June 23). Dukungan Pemerintah Sama, Kenapa Ada Operator Telekomunikasi Lebih Unggul? Retrieved from http://ekonomi.kompas.com/read/2016/06/23/120047726/dukungan.pemerintah.sama.kenapa ada.operator.telekomunikasi.lebih.unggul.

Kompas. (2016, November 25). Telkomsel Fokus Perluasan dan Penambahan Kapasitas Jaringan Retrieved from http://tekno.kompas.com/read/2016/11/25/14060017/2017.telkomsel.fokus.perluasan.dan.pe nambahan.kapasitas.jaringan

Modjo, Mohamad Ikhsan. 2008. Aspek Ekonomi dan Persaingan pada Industri Telekomunikasi Seluler. Bisnis \& Ekonomi Politik, Vol.9 (1): 41-49.

Muladi. 1998. Menyongsong Keberadaan UU Persaingan Sehat di Indonesia, dalam UU Antimonopoli Seperti Apakah yang Sesungguhnya Kita Butuhkan? Newsletter No. 34 Tahun IX. Jakarta: Yayasan Pusat Pengkajian Hukum.

Sirait, Ningrum Natasya. (2004). Hukum Persaingan di Indonesia. Medan: Pustaka Bangsa Press. Siswanto, Ari. (2002). Hukum Persaingan Usaha. Jakarta: Ghalia Indonesia.

Sugiyono. (2010). Metode Penelitian Administrasi. Bandung: Alfabeta.

Umar, Husein. (2000). Metode Penelitian untuk Skripsi dan Tesis Bisnis. Jakarta: Raja Grafindo Persada.

Viva. (2017, Juli 27). Kata Indosat soal Pembangunan BTS di Daerah Terpencil. Retrieved from http://m.viva.co.id/digital/940245-kata-indosat-soal-pembangunan-bts-di-daerah-terpencil 